\title{
Assessment criteria for vitamin D deficiency/insufficiency in Japan - proposal by an expert panel supported by Research Program of Intractable Diseases, Ministry of Health, Labour and Welfare, Japan, The Japanese Society for Bone and Mineral Research and The Japan Endocrine Society
}

Ryo Okazaki $^{1)}$, Keiichi Ozono ${ }^{2)}$, Seiji Fukumoto ${ }^{3)}$, Daisuke Inoue ${ }^{1)}$, Mika Yamauchi ${ }^{4)}$, Masanori Minagawa $^{5)}$, Toshimi Michigami ${ }^{6)}$, Yasuhiro Takeuchi ${ }^{7)}$, Toshio Matsumoto ${ }^{3)}$ and Toshitsugu Sugimoto ${ }^{4)}$

1) Third Department of Medicine, Teikyo University Chiba Medical Center, Ichihara 299-0111, Japan

2) Department of Pediatrics, Osaka University Graduate School of Medicine, Suita 565-0871, Japan

3) Fujii Memorial Institute of Medical Sciences, Tokushima University, Tokushima 770-8503, Japan

4) Internal Medicine 1, Shimane University Faculty of Medicine, Izumo 693-8501, Japan

5) Department of Endocrinology, Chiba Children's Hospital, Chiba 266-0007, Japan

6) Department of Bone and Mineral Research, Research Institute, Osaka Medical Center for Maternal and Child Health, Izumi 594-1101, Japan

7) Division of Endocrinology, Toranomon Hospital Endocrine Center, Tokyo 105-8470, Japan

\begin{abstract}
Vitamin D is indispensable for the maintenance of bone and mineral health. Inadequate vitamin D action increases the risk for various musculoskeletal/mineral events including fracture, fall, secondary hyperparathyroidism, diminished response to antiresorptives, rickets/osteomalacia, and hypocalcemia. Its most common cause in recent years is vitamin D deficiency/insufficiency, clinically defined by low serum 25-hydroxyvitamin D [25(OH)D] level. Guidelines for vitamin D insufficiency/deficiency defined by serum 25(OH)D concentrations have been published all over the world. In Japan, however, the information on the associations between serum $25(\mathrm{OH}) \mathrm{D}$ and bone and mineral disorders has not been widely shared among healthcare providers, partly because its measurement had not been reimbursed with national medical insurance policy until August 2016. We have set out to collect and analyze Japanese data on the relationship between serum $25(\mathrm{OH}) \mathrm{D}$ concentration and bone and mineral events. Integrating these domestic data and published guidelines worldwide, here we present the following assessment criteria for vitamin D sufficiency/insufficiency/deficiency using serum 25(OH)D level in Japan. 1) Serum 25(OH)D level equal to or above $30 \mathrm{ng} / \mathrm{mL}$ is considered to be vitamin $\mathrm{D}$ sufficient. 2) Serum 25(OH)D level less than $30 \mathrm{ng} / \mathrm{mL}$ but not less than $20 \mathrm{ng} / \mathrm{mL}$ is considered to be vitamin D insufficient. 3) Serum $25(\mathrm{OH}) \mathrm{D}$ level less than $20 \mathrm{ng} / \mathrm{mL}$ is considered to be vitamin D deficient. We believe that these criteria will be clinically helpful in the assessment of serum $25(\mathrm{OH}) \mathrm{D}$ concentrations and further expect that they will form a basis for the future development of guidelines for the management of vitamin D deficiency/insufficiency.
\end{abstract}

Key words: Vitamin D, Vitamin D deficiency, 25-hydroxyvitamin D, Fracture, PTH

\section{Definition and Significance}

Normal vitamin $\mathrm{D}$ action is indispensable for the maintenance of bone and mineral metabolism. Inadequate vitamin $\mathrm{D}$ action results in various abnor-

Submitted Nov. 9, 2016; Accepted Nov. 11, 2016 as EJ16-0548 Released online in J-STAGE as advance publication Dec. 20, 2016 Correspondence to: Ryo Okazaki, M.D., Ph.D., Third Department of Medicine, Teikyo University Chiba Medical Center, Ichihara 299-0111, Japan. E-mail: rokazaki@med.teikyo-u.ac.jp

CThe Japan Endocrine Society malities in bone and mineral metabolism, including an increase in fracture risk. The most common cause of diminished vitamin $\mathrm{D}$ action at present days is vitamin $\mathrm{D}$ insufficiency/deficiency, a decrease in body stores of vitamin D. Vitamin D status can only be assessed with measurement of serum 25-hydroxyvitamin D [25(OH) D]. Guidelines for vitamin D insufficiency/deficiency defined by serum $25(\mathrm{OH}) \mathrm{D}$ concentrations have been published from many countries and regions all over the world [1-5]. In Japan, however, the information 
on the associations between serum 25(OH)D and bone and mineral disorders has not been widely shared among healthcare providers, partly because serum 25(OH)D measurement had not been reimbursed with national medical insurance policy until August 2016. Thus, we have set out to collect and analyze Japanese data on the relationship between serum $25(\mathrm{OH}) \mathrm{D}$ concentration and bone and mineral events such as osteoporotic fractures. Integrating these domestic data and published guidelines worldwide, here we present the first version of assessment criteria for vitamin D sufficiency/insufficiency/deficiency using serum $25(\mathrm{OH}) \mathrm{D}$ level in Japan (Table 1).

In the present assessment criteria, as in the 2011 US Endocrine Society guideline [1], we use the term "vitamin D insufficiency" for relatively mild vitamin D insufficient state, and the term "vitamin D deficiency" for severe vitamin D insufficient state. Clinically, both vitamin $\mathrm{D}$ insufficiency and deficiency may cause increases in fracture and fall risks, secondary hyperparathyroidism, and poor responses to antiresorptives. Vitamin D deficiency can further cause rickets/osteomalacia and hypocalcemia.

The present assessment criteria are not guidelines for the diagnosis of vitamin D deficiency/insufficiency. Development of clinical guidelines including needs for medical intervention will be a future task.

\section{Explanations}

\section{Clinical definition and significance of vitamin $D$ insufficiency/deficiency}

Vitamin D insufficiency/deficiency is a state where body stores of vitamin $\mathrm{D}$ decrease, which may result in insufficient vitamin D action. Animals including human can synthesize vitamin $\mathrm{D}_{3}$ in the skin using ultraviolet energy. Plants contain vitamin $\mathrm{D}_{2}$. Both vitamin $\mathrm{D}_{3}$ and $\mathrm{D}_{2}$ follow the same metabolism, and their actions are qualitatively the same. Thus, we use the collective term "vitamin D". Most vitamin D synthesized in the skin or orally ingested is converted to $25(\mathrm{OH}) \mathrm{D}$ in the liver. $25(\mathrm{OH}) \mathrm{D}$ makes a stable complex with vitamin D binding protein (DBP) in the circulation. Because the half-life of circulating $25(\mathrm{OH})$ $\mathrm{D}$ is relatively long, about 3 weeks, serum $25(\mathrm{OH}) \mathrm{D}$ level is considered to reflect the amount of vitamin D stores. Therefore, vitamin D insufficiency/deficiency is clinically defined as a state characterized by low serum $25(\mathrm{OH}) \mathrm{D}$, which may result in insufficient vitamin $\mathrm{D}$ action.

Classical action of vitamin D is the maintenance of bone and mineral metabolism. Abnormalities resulting from insufficient classical action of vitamin D are listed in the Fig. 1. Insufficient action of vitamin D can result in impaired absorption of calcium $(\mathrm{Ca})$ and phosphate $(\mathrm{P})$ from the intestine, thereby causing hypocalcemia and/or hypophosphatemia. Such abnormalities may in turn impair bone mineralization, resulting in rickets/osteomalacia, and may also cause secondary hyperparathyroidism further leading to stimulated bone resorption and decreased bone mineral density. In addition, low serum $25(\mathrm{OH}) \mathrm{D}$ level is a risk factor for falling. Altogether, fracture risk increases with low serum 25(OH)D level. The lower the serum 25(OH) $\mathrm{D}$ level is, the higher is the risk of those abnormalities. Low serum 25(OH)D level has also been reported to be associated with poor responses to antiresorptive medications (Fig. 1).

Table 1 Assessment criteria for vitamin D deficiency/insufficiency in Japan

1) Serum $25(\mathrm{OH}) \mathrm{D}$ level equal to or above $30 \mathrm{ng} / \mathrm{mL}$ is considered to be vitamin $\mathrm{D}$ sufficient.

2) Serum $25(\mathrm{OH}) \mathrm{D}$ level less than $30 \mathrm{ng} / \mathrm{mL}$ is considered to be not vitamin $\mathrm{D}$ sufficient.

a) Serum 25(OH)D level less than $30 \mathrm{ng} / \mathrm{mL}$ but not less than $20 \mathrm{ng} / \mathrm{mL}$ is considered to be vitamin D insufficient.

b) Serum $25(\mathrm{OH}) \mathrm{D}$ level less than $20 \mathrm{ng} / \mathrm{mL}$ is considered to be vitamin $\mathrm{D}$ deficient.

Notes

1. Serum 25(OH)D level may vary depending on the assays used. Standardization of the assay will be needed.

2. Different criteria may be needed for children and pregnant or lactating women. On nutritional vitamin D deficient rickets in children, there is a published global consensus [6].

3. These assessment criteria have been established from the standpoint of bone and mineral metabolism.

4. Besides bone and mineral abnormalities, many disorders including cancers, metabolic, cardiovascular and immunological diseases have been linked to low serum 25(OH)D levels. Most such studies have however been conducted overseas. And no vitamin D guidelines have dealt with potential vitamin $\mathrm{D}$ actions beyond bone and mineral metabolism. Thus, the present assessment criteria will not consider vitamin $\mathrm{D}$ actions beyond bone and mineral metabolism. 


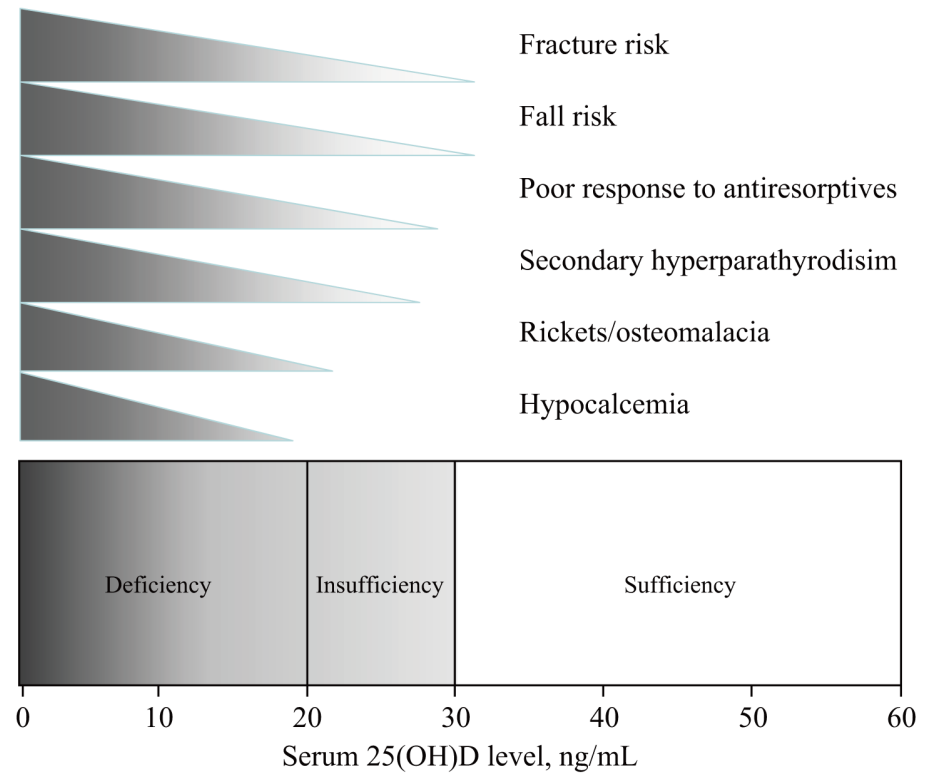

Fig. 1 Serum 25(OH)D level and skeletal/mineral events (Concept)

The lower the serum 25(OH)D level is, the higher the risk is for the musculoskeletal/mineral events. Note that each event has a unique threshold 25(OH)D level.

Besides 25(OH)D, other vitamin D metabolites such as $1 \alpha, 25$-dihydroxyvitamin $\mathrm{D}$ or $1,25(\mathrm{OH})_{2} \mathrm{D}$, which is $1 \alpha$-hydroxylated $25(\mathrm{OH}) \mathrm{D}$ in the proximal tubules, are present in circulation. Most vitamin D actions are mediated by the vitamin $\mathrm{D}$ receptor (VDR), a member of the nuclear receptor super-family. Among physiological vitamin $\mathrm{D}$ metabolites, $1,25(\mathrm{OH})_{2} \mathrm{D}$ has the highest affinity to VDR. Until recently physiological production of $1,25(\mathrm{OH})_{2} \mathrm{D}$ had been considered to be restricted to the proximal tubule. However, recent studies have revealed that $1 \alpha$-hydroxylase is present in vitamin D target organs such as bone $[7,8]$ and parathyroid $[9,10]$, and that cells in those tissues can produce $1,25(\mathrm{OH})_{2} \mathrm{D}$. Therefore, vitamin $\mathrm{D}$ actions in these target organs are not only brought by circulating $1,25(\mathrm{OH})_{2} \mathrm{D}$ produced in the kidney, but most likely exerted also by $1,25(\mathrm{OH})_{2} \mathrm{D}$ locally produced from $25(\mathrm{OH}) \mathrm{D}$ taken up from the circulation into the cell, concentration of which is approximately 1,000 times higher than that of $1,25(\mathrm{OH})_{2} \mathrm{D}$ in the blood.

In vitamin D deficiency/insufficiency, associated hypophosphatemia and secondary hyperparathyroidism may stimulate $1 \alpha$-hydroxylase in the proximal tubule, frequently resulting in high serum $1,25(\mathrm{OH})_{2} \mathrm{D}$ level. Indeed, serum $1,25(\mathrm{OH})_{2} \mathrm{D}$ levels in vitamin $\mathrm{D}$ deficiency/insufficiency cases have been reported to be normal, high, or low. In addition, half-life of circulating
$1,25(\mathrm{OH})_{2} \mathrm{D}$ is less than a day. Thus, serum $1,25(\mathrm{OH})_{2} \mathrm{D}$ level reflects neither tissue vitamin $\mathrm{D}$ actions, nor the vitamin D status.

\section{Relationship between serum 25(OH)D level and bone/ mineral events in the Japanese 1) Fracture}

Several Japanese observational studies have reported associations between low serum 25(OH)D levels and osteoporotic fractures including hip fractures. One study reported that the mean serum $25(\mathrm{OH})$ D level of 50 patients admitted for hip fracture was $17.8 \mathrm{ng} / \mathrm{mL}$, which was significantly lower than that of 53 non-hip fracture control patients $(25.8 \mathrm{ng} / \mathrm{mL})$ [11]. Another study reported that the mean serum $25(\mathrm{OH})$ D level of 225 patients who visited an hospital for hip fracture was $16.3 \mathrm{ng} / \mathrm{mL}$, significantly lower than 18.1 $\mathrm{ng} / \mathrm{mL}$, the mean serum $25(\mathrm{OH}) \mathrm{D}$ level of 63 patients who had new clinical vertebral fracture during the same period [12]. Others [13] reported that among 330 untreated postmenopausal Japanese women who visited an orthopedic clinic, prevalent vertebral fractures were more frequent in those with serum $25(\mathrm{OH})$ D level less than $20 \mathrm{ng} / \mathrm{mL}$ than in those with $20 \mathrm{ng} /$ $\mathrm{mL}$ or more. There is also a report [14] demonstrating that, among 202 postmenopausal Japanese women, the mean serum $25(\mathrm{OH}) \mathrm{D}$ level in those with preva- 
lent fractures was $14.6 \mathrm{ng} / \mathrm{mL}$, which was significantly lower than that in those without. Muramatsu study [15], a 6-year cohort study of 773 community dwelling women in Niigata prefecture, revealed that fracture risk was significantly lower in subjects with basal serum 25(OH)D level being more than $28.4 \mathrm{ng} / \mathrm{mL}$ compared with the others with lower $25(\mathrm{OH}) \mathrm{D}$ level, with the hazard ratio of 0.41 (95\% CI $0.18-0.91)$. Another cohort study of 1,470 postmenopausal women conducted in Nagano prefecture with a mean observation period of 7.2 years [16] revealed that those with basal serum 25(OH)D level less than $25 \mathrm{ng} / \mathrm{mL}$ showed a significantly higher risk of long-bone fracture. Finally, the Japanese Population-based Osteoporosis (JPOS) study [17] reported that among 1,262 postmenopausal women, 5-year total fracture incidence was highest in the group with basal serum $25(\mathrm{OH})$ D level less than $10 \mathrm{ng} / \mathrm{mL}$, followed by those with between 10 and $20 \mathrm{ng} / \mathrm{m}$ and 20-30 ng/mL, and the lowest in the group above $30 \mathrm{ng} / \mathrm{mL}$.

\section{2) Bone mineral density (BMD)}

Yokogoshi study [18] conducted in Niigata prefecture reported that serum $25(\mathrm{OH}) \mathrm{D}$ level was positively associated with femoral neck BMD, which was more frequently in the osteoporotic range in subjects with serum 25(OH)D level less than $20 \mathrm{ng} / \mathrm{mL}$ compared with control subjects with above $28 \mathrm{ng} / \mathrm{mL}$. At least another Japanese study reported positive correlation between BMD and serum 25(OH)D level [14]. A recent study of 1,380 Japanese male and female teenagers between 12 and 18 years old reported positive correlations between serum $25(\mathrm{OH}) \mathrm{D}$ and calcaneal stiffness, which was significantly lower in those with serum 25(OH)D less than $20 \mathrm{ng} / \mathrm{mL}$ [19].

\section{3) Parathyroid hormone (PTH)}

Several cross-sectional studies reported negative correlation between serum PTH and serum 25(OH)D levels in the Japanese [17,20], which may be explained by locally produced $1,25(\mathrm{OH})_{2} \mathrm{D}$ in the parathyroid glands. A Japanese study investigating PTH responsiveness to vitamin $\mathrm{D}_{3}$ loading estimated that serum $25(\mathrm{OH}) \mathrm{D}$ level of $28 \mathrm{ng} / \mathrm{mL}$ would be the minimal threshold to prevent PTH hypersecretion [20]. Among cross-sectional studies, in aforementioned Yokogoshi study [18], serum PTH level was significantly higher in subjects with serum 25(OH)D level being less than $20 \mathrm{ng} / \mathrm{mL}$. The Research on Osteoarthritis/osteoporosis Against Disability (ROAD) study [21] reported that PTH level was highest in the group with serum $25(\mathrm{OH})$
D less than $10 \mathrm{ng} / \mathrm{mL}$, followed by the group with 10 to $30 \mathrm{ng} / \mathrm{mL}$, and lowest in those above $30 \mathrm{ng} / \mathrm{mL}$, and that the difference among three groups was significant. 4) Fall

A study of the community dwelling elderly reported that serum 25(OH)D level less than $20 \mathrm{ng} / \mathrm{mL}$ was associated with the higher fall incidence in the previous year among women aged 65 years old more [22]. Follow-up study revealed that serum 25(OH)D level less than $20 \mathrm{ng} / \mathrm{mL}$ was also associated with the higher fall incidence in the following year among women over 75 years old [23].

\section{5) Responsiveness to antiresorptive medications}

Ishijima et al. reported that serum 25(OH)D level less than $25 \mathrm{ng} / \mathrm{mL}$ was associated with significantly weaker BMD response to alendronate [24]. Reports from other countries indicated serum $25(\mathrm{OH}) \mathrm{D}$ levels less than $30-32 \mathrm{ng} / \mathrm{mL}$ were associated with poorer BMD responses to bisphosphonates and selective estrogen receptor modulators or with increased fracture incidence during anti-osteoporotic pharmaceutical treatment [25-28].

\section{6) Osteomalacia and rickets}

According to the "Pathogenesis and diagnostic criteria for rickets and osteomalacia--proposal by an expert panel supported by the Ministry of Health, Labour and Welfare, Japan, the Japanese Society for Bone and Mineral Research, and the Japan Endocrine Society" [29], serum 25(OH)D level less than $20 \mathrm{ng} / \mathrm{mL}$ may cause vitamin D deficient rickets/osteomalacia. "Global Consensus Recommendations on Prevention and Management of Nutritional Rickets" [6] indicated that serum $25(\mathrm{OH}) \mathrm{D}$ level less than $12 \mathrm{ng} / \mathrm{mL}$ or $20 \mathrm{ng} / \mathrm{mL}$ combined with $\mathrm{Ca}$ intake deficiency increase the risk of nutritional rickets in children. On the other hand, a German study of 665 adults autopsy reported that serum $25(\mathrm{OH}) \mathrm{D}$ level up to $30 \mathrm{ng} / \mathrm{mL}$ was associated with histological mineralization defect [30].

\section{7) Hypocalcemia}

"The Guide for the Differential Diagnosis of Hypocalcemia" compiled by the Japan Endocrine Society [31] indicated that serum $25(\mathrm{OH}) \mathrm{D}$ level less than $15 \mathrm{ng} / \mathrm{mL}$ is highly suggestive of the diagnosis of hypocalcemia due to vitamin $\mathrm{D}$ deficiency.

\section{Disclosure}

None of the authors have any potential conflicts of interest associated with this research. 


\section{References}

1. Holick MF, Binkley NC, Bischoff-Ferrari HA, Gordon CM, Hanley DA, et al. (2011) Evaluation, treatment, and prevention of vitamin D deficiency: an Endocrine Society clinical practice guideline. J Clin Endocrinol Metab 96: 1911-1930.

2. Institute of Medicine (US) Committee to Review Dietary Reference Intakes for Vitamin D and Calcium (2011) Dietary reference intakes for calcium and vitamin D. The National Academies Press, Washington, DC.

3. Dawson-Hughes B, Mithal A, Bonjour JP, Boonen S, Burckhardt P, et al. (2010) IOF position statement: vitamin D recommendations for older adults. Osteoporos Int 21: 1151-1154.

4. Hanley DA, Cranney A, Jones G, Whiting SJ, Leslie WD, et al. (2010) Vitamin D in adult health and disease: a review and guideline statement from Osteoporosis Canada. CMAJ 182: E610-618.

5. Cosman F, de Beur SJ, LeBoff MS, Lewiecki EM, Tanner B, et al. (2014) Clinician's Guide to Prevention and Treatment of Osteoporosis. Osteoporos Int 25: 2359-2381.

6. Munns CF, Shaw N, Kiely M, Specker BL, Thacher TD, et al. (2016) Global Consensus Recommendations on Prevention and Management of Nutritional Rickets. $J$ Clin Endocrinol Metab 101: 394-415.

7. van Driel M, van Leeuwen JP (2014) Vitamin D endocrine system and osteoblasts. Bonekey Rep 3: 493.

8. van der Meijden K, van Essen HW, Bloemers FW, Schulten EA, Lips P, et al. (2016) Regulation of CYP27B1 mRNA Expression in Primary Human Osteoblasts. Calcif Tissue Int 99: 164-173.

9. Segersten U, Correa P, Hewison M, Hellman P, Dralle $\mathrm{H}$, et al. (2002) 25-hydroxyvitamin $\mathrm{D}(3)$-1alphahydroxylase expression in normal and pathological parathyroid glands. J Clin Endocrinol Metab 87: 2967-2972.

10. Ritter CS, Haughey BH, Armbrecht HJ, Brown AJ (2012) Distribution and regulation of the 25-hydroxyvitamin D3 1alpha-hydroxylase in human parathyroid glands. J Steroid Biochem Mol Biol 130: 73-80.

11. Sakuma M, Endo N, Oinuma T, Hayami T, Endo E, et al. (2006) Vitamin D and intact PTH status in patients with hip fracture. Osteoporos Int 17: 1608-1614.

12. Sakuma M, Endo N, Hagino H, Harada A, Matsui Y, et al. (2011) Serum 25-hydroxyvitamin D status in hip and spine-fracture patients in Japan. J Orthop Sci 16: 418-423.

13. Ikegami S, Kamimura M, Uchiyama S, Kato H (2011) Women with insufficient 25-hydroxyvitamin D without secondary hyperparathyroidism have altered bone turnover and greater incidence of vertebral fractures. $J$ Orthop Sci 16: 573-580.

14. Yamauchi M, Kaji H, Nawata K, Takaoka S, Yamaguchi
T, et al. (2011) Role of parathyroid hormone in bone fragility of postmenopausal women with vitamin D insufficiency. Calcif Tissue Int 88: 362-369.

15. Nakamura K, Saito T, Oyama M, Oshiki R, Kobayashi $\mathrm{R}$, et al. (2011) Vitamin D sufficiency is associated with low incidence of limb and vertebral fractures in community-dwelling elderly Japanese women: the Muramatsu Study. Osteoporos Int 22: 97-103.

16. Tanaka S, Kuroda T, Yamazaki Y, Shiraki Y, Yoshimura $\mathrm{N}$, et al. (2014) Serum 25-hydroxyvitamin D below 25 $\mathrm{ng} / \mathrm{mL}$ is a risk factor for long bone fracture comparable to bone mineral density in Japanese postmenopausal women. J Bone Miner Metab 32: 514-523.

17. Tamaki J, Iki M, Sato H, Kajita E, Nishino O, et al. (2015) Low serum 25(OH)D level increases fracture risk: the Japanese Population-based Osteoporosis (JPOS) cohort study. Dai 33-Kai Nihon Kotsutaisha Gakkai Gakujyutsu Shukai Programu Shoroku Shu (Program of the 33rd Meeting of the Japanese Society for Bone and Mineral Research) A177 (Abstract) (In Japanese).

18. Nakamura $K$, Tsugawa $N$, Saito $T$, Ishikawa $M$, Tsuchiya Y, et al. (2008) Vitamin D status, bone mass, and bone metabolism in home-dwelling postmenopausal Japanese women: Yokogoshi Study. Bone 42: 271-277.

19. Tsugawa N, Uenishi K, Ishida H, Ozaki R, Takase T, et al. (2016) Association between vitamin D status and serum parathyroid hormone concentration and calcaneal stiffness in Japanese adolescents: sex differences in susceptibility to vitamin D deficiency. J Bone Miner Metab 34: 464-474.

20. Okazaki R, Sugimoto T, Kaji H, Fujii Y, Shiraki M, et al. (2011) Vitamin D insufficiency defined by serum 25-hydroxyvitamin D and parathyroid hormone before and after oral vitamin $\mathrm{D}(3)$ load in Japanese subjects. $J$ Bone Miner Metab 29: 103-110.

21. Yoshimura N, Muraki S, Oka H, Morita M, Yamada $\mathrm{H}$, et al. (2013) Profiles of vitamin D insufficiency and deficiency in Japanese men and women: association with biological, environmental, and nutritional factors and coexisting disorders: the ROAD study. Osteoporos Int 24: 2775-2787.

22. Suzuki T, Kwon J, Kim H, Shimada H, Yoshida Y, et al. (2008) Low serum 25-hydroxyvitamin D levels associated with falls among Japanese community-dwelling elderly. J Bone Miner Res 23: 1309-1317.

23. Shimizu Y, Kim H, Yoshida H, Shimada H, Suzuki T (2015) Serum 25-hydroxyvitamin D level and risk of falls in Japanese community-dwelling elderly women: a 1-year follow-up study. Osteoporos Int 26: 2185-2192.

24. Ishijima M, Sakamoto Y, Yamanaka M, Tokita A, Kitahara K, et al. (2009) Minimum required vitamin D 
level for optimal increase in bone mineral density with alendronate treatment in osteoporotic women. Calcif Tissue Int 85: 398-404.

25. Adami S, Giannini S, Bianchi G, Sinigaglia L, Di Munno O, et al. (2009) Vitamin D status and response to treatment in post-menopausal osteoporosis. Osteoporos Int 20: 239-244.

26. Carmel AS, Shieh A, Bang H, Bockman RS (2012) The $25(\mathrm{OH}) \mathrm{D}$ level needed to maintain a favorable bisphosphonate response is $\geq 33 \mathrm{ng} / \mathrm{ml}$. Osteoporos Int 23 : 2479-2487.

27. Diez-Perez A, Olmos JM, Nogues X, Sosa M, DiazCuriel M, et al. (2012) Risk factors for prediction of inadequate response to antiresorptives. $J$ Bone Miner Res 27: 817-824.

28. Peris P, Martinez-Ferrer A, Monegal A, Martinez de Osaba MJ, Muxi A, et al. (2012) 25 hydroxyvitamin D serum levels influence adequate response to bisphos- phonate treatment in postmenopausal osteoporosis. Bone 51: 54-58.

29. Fukumoto S, Ozono K, Michigami T, Minagawa M, Okazaki R, et al. (2015) Pathogenesis and diagnostic criteria for rickets and osteomalacia - proposal by an expert panel supported by Ministry of Health, Labour and Welfare, Japan, The Japanese Society for Bone and Mineral Research and The Japan Endocrine Society. Endocr J 62: 665-671.

30. Priemel M, von Domarus C, Klatte TO, Kessler S, Schlie J, et al. (2010) Bone mineralization defects and vitamin D deficiency: histomorphometric analysis of iliac crest bone biopsies and circulating 25-hydroxyvitamin D in 675 patients. J Bone Miner Res 25: 305-312.

31. The Japan Endocrine Society. The Guide for the Differential Diagnosis of Hypocalcemia. http://endocrine.umin.ac.jp/tebiki/003/003001.pdf (In Japanese). 